\title{
The Correlation Analysis of the Green Credit Policy and the Operating Performance of the Listed Banks in China
}

\author{
Xiaoling Song, Mengdi Wei \\ Business School, Beijing Language and Culture University, Beijing, 100083, China
}

Keywords: green credit policy, operating performance, listed banks

\begin{abstract}
Sixteen listed banks in China have established relevant regulations on green credit, and policy implementation has begun showing early results. Implementation of green credit policies can create benefits for banks, which have critical effect on establishing good mage and reputation so as to promote the improvement of business performance. This paper has selected non-performing loan ratio, cost-income ratio, ROE, and other financial indexes in 16 Chinese listed banks for analysis. Research indicates that there exist a positive correlation between the implementation strength of green credit loan policies and business performance of listed banks.
\end{abstract}

\section{Introduction}

Environment pollution has become a focus issue arousing the world attention. To restrict the blind expansion of relevant industries, and relieve the pollution damage to human beings, SEPA, Bank of China, and CBRC have jointly proposed "green credit" policy which was executed since July 2007. As a new type business pattern, green credit has improved the environmental protection threshold for enterprise financing and promoted eco protection and economic sustainable development.

Scholars hold different views of the research spotlight, green credit. Jeucken (2002) believes that green credit with financing policy as media deserves support for environmentally friendly business projects. Bank departments provide loan business for these projects and use various knowledge and information allocation means to achieve the strategic target of stimulating economic sustainable development. Labatt and White (2002) indicate that green credit covering broad contents include characteristic financial tools in the market within its range. During the process of environment quality and environment risk transfer, these financial tools can give their full play. Paul Thompson and Cowton (2004) believe that green credit essentially requires banks' strict auditing during the loan process and incorporation environment related information as important standard so as to make decision of whether providing loans or not under the effect of the mechanism.

Despite of inconsistent views in academic circle and practical field, green credit has been given meanings in two levels: firstly, to promote enterprises to save resources and reduce pollution. During business accounting and decision-making in financial industry, ecological environmental factor has been integrated so as to get enterprises out of the wrong area of environmental pollution and avoid causing greater resource waste. Secondly, for human long-term development, financial industry has paid close attention to environmental protection and take measures for promoting ecological industry development. Financial industry will inevitably get repaid if ecological economy obtains good benefits in the future, which is good for mutual development of finance and ecology and a win-win good situation. 


\section{Implementation Effect of Green Credit Policy of Chinese Listed Banks}

\subsection{Current Situation of Green Credit Policy Implementation of Chinese Listed Banks}

\subsubsection{Green Credit Loan System Construction}

Chinese 16 listed banks have established green credit regulations. Credit control system in "two high one excess" industries are important contents of green credit system. Banks have issued loan scale control measures in "two high one excess" industry. Most banks use "one vote veto environmental protection", and also use quota management, list system management and limit of examining and approving.

\subsubsection{Green Financial Product Innovation}

Except for traditional energy-saving and emission reduction project financing, bank green financial product innovation has strong purposefulness mainly in three aspects: energy efficiency financing, clean resource financing, emission right finance, green equipment supply chain financing. Compared with large-scale state-owned commercial banks, CIB, SPDB, CEB and other joint-stock banks are taking the lead in green financial product innovation.

\subsubsection{Implementation Effect of Green Credit Policy}

The proportion of loan balance of green credit domain in total credit balance, and the proportion of "two high one excess" industry loan in total loan balance can be used to measure the strength and effect of listed banks' implementation of national green credit policies. Banks have begun implementing national green credit policies from operation level, and gradually increased the support for energy saving and emission reduction projects. Only four banks have green credit loan balance over RMB 0.1 trillion in 2011, Bank of China, Bank of Communication, CCB and Industrial and Commercial Bank of China. After two years, the number has increased by seven including Agricultural Bank of China, five state-owned commercial banks, two joint-stock banks including CIB and CMBC. Regarding the relevant proportion, banks with green credit loan accounting for 5\% of enterprise loan sum for successive three years include three state-owned banks ICBC, BOC and Bank of Communications, and two joint-stock banks CIB and CMBC. Among 16 listed banks, the top five banks with largest green credit balance in 2011 and 2012 are ICBC, Bank of China, CCB, Bank of Communications and Agricultural Bank of China. But since 2013, CIB has exceeded Bank of Communications in terms of green credit balance and entered into top five. From above information, the proportion of green credit balance in commercial banks is increasing year by year. Five state-owned commercial banks and joint-stock banks including CIB and CMBC have important effect. But in terms of the loan amount and proportion of environment protection projects, domestic commercial bank investment is not high.

\subsubsection{Green Credit Information Disclosure Condition}

Sixteen listed banks have disclosed green credit and "two high one excess" industry loan information. Except Bank of Beijing, Bank of Nanjing, Bank of Ningbo and CIB, other 12 banks have conducted third-party inspection of green credit information and other social responsibility information disclosed in their social responsibility report.

\subsection{Relationship Between Green Credit Policy Implementation and Bank Business Performance}

Listed banks undertake environmental social responsibilities for improving business performance and promoting sustainable development. Implementing green credit policies can create benefits for banks, and have critical effect on establishing good image and reputation. From strategic management perspective, it can strengthen bank core competitiveness, reduce environmental risk and trade cost. Thus, during listed banks' operation and development, awareness of optimizing environment at any time can bring win-win result for banks and the society. So, the general 
relationship between green credit policy implementation and bank business performance is: the greater implementation strength of green credit policy, the better business performance.

\subsection{Problems Existing in Listed Banks' Green Credit Policy Implementation}

\subsubsection{Green Credit Loan System Construction Needs to Be Perfected}

Even 16 listed banks have established green credit related system and measures, and formed multi-level green credit system from bank to supervisory department and government, green credit full-duty organization setting is not idea from the perspective of implementation mechanism without green credit working evaluation and examination mechanism. Except for CIB and CMBC, SPDB, and CEB which have set full-duty green credit departments, other banks or enterprise cultural department, PR department or other organizations exercise green credit function without departments to clearly executing green credit. Green credit working examination and evaluation mechanism inside banks are deficient. Except for CIB, other banks have not established green credit working examination and evaluation mechanism. The lack of green credit policy exterior supervision restriction mechanism and incentive mechanism are important influencing factors that banks lack green credit evaluation pressure and momentum.

\subsubsection{Green Credit Loan Balance Is Few and Proportion is Low}

Despite of sharp increase of green credit loan sum in recent years, generally speaking, the proportion of green credit among enterprise loan sum is still in a low condition. Currently, the effect of green credit is mainly shown manifested as control of "two high one excess" industry loan scale with administrative order but the green credit loan which uses market to promote energy saving and emission reduction has not given its full play.

\subsubsection{Supervision and Incentive Mechanism is Not Mature}

Due to the lack of supervisory restriction mechanism and incentive mechanism, banks launch green credit out of political motivation or the motivation of performing social responsibility and improving enterprise image. Without the motivation to actively develop new products and new business, poor innovation of green financial products, market effect cannot be fully played so that green credit balance is hard to increase.

\section{Empirical Test of the Correlation Between Chinese Listed Banks' Green Credit Policy with Business Performance}

Based on the analysis on the second part, assume the greater implementation strength of green credit policy, the better business effect. This part will make empirical test on this assumption.

\subsection{Index Selection}

\subsubsection{Index Selection of Green Credit Policy Implementation}

According to the performance standard and relevant indication of equator principle, this paper has constructed index system. First-level indexes include green credit policy formulation and implementation situation. The former includes second indexes as follows: standard formulation situation, receive the management of international restrictive standard, construct responsibility mechanism and guarantee its function, construct branch guidance policy, provide social responsibility report and receive third-party authentication. The latter includes open green financing new products, execute one vote veto environmental protection, increase the strength of environmental friendly project loans, and actively participate in social activity and supervision. 


\subsubsection{Index Selection of Listed Bank Business Performance}

Select ROE to measure its business performance. Calculation formula: ROE=net profit + the beginning and closing net asset mean

ROE reflects listed banks' ability to use own capital to profit. If ROE in high state, self-assets have strong profitability with better guarantee for stockholders and creditors. So when measuring bank business performance, select ROE as the index.

\subsubsection{Selection of Control Variables}

Regard bank scale as control variable and scale is described by closing asset sum. Due to the large amount of bank total assets, select the logarithm in actual data processing. Table 1 shows each variable's name abbreviation

Table 1. Table of each variable's name abbreviation

\begin{tabular}{|c|c|c|c|}
\hline Variable type & Variable name & Variable definition & Variable abbreviation \\
\hline Explained variable & Return on equity & Net profit/average net assets & ROE \\
\hline Explanatory variable & $\begin{array}{c}\text { Green credit } \\
\text { implementation condition }\end{array}$ & $\begin{array}{c}\text { Green credit policy } \\
\text { implementation strength }\end{array}$ \\
\hline Control variable & Bank scale & Natural logarithm of asset sum & Lnscale \\
\hline
\end{tabular}

\subsection{Sample Data Source and Preliminary Analysis}

Select data of16 listed banks in 2010 to 2014 as research samples including five state-owned banks: ICBC, BOC, CCB, ABC, Bank of Communications, 8 joint-stock banks including CMSB, Pudong Development Bank, CMBC, Ping An Bank, CITIC Bank, CIB, HXB, CEB; 3 city banks including Bank of Beijing, Bank of Nanjing, Bank of Ningbo and CIB. Green credit index data come from social responsibility report issued by each bank; performance data come from annual report, comprehensive financial statement and social responsibility report issued by each bank in SSE and SZSE. Each index data statistics are shown in Table 2.

Table 2. Each index data statistic table

\begin{tabular}{|c|c|c|c|c|c|}
\hline Variable & Variable name & Minim value & Max value & Mean value & $\begin{array}{c}\text { Standard } \\
\text { deviation }\end{array}$ \\
\hline ROE & ROE & 0.1487 & 0.2665 & 0.2019 & 0.0262 \\
\hline GCR & $\begin{array}{c}\text { Green credit policy } \\
\text { implementation strength }\end{array}$ & 0.1 & 0.9 & 0.5280 & 0.1708 \\
\hline Lnscale & Enterprise scale & 11.3454 & 13.3141 & 12.4903 & 0.5179 \\
\hline
\end{tabular}

\subsection{Correlation Analysis and Regression Test}

Variable correlation analysis and regression test see table 3.

Table 3. Variable correlation analysis and regression test form

\begin{tabular}{|c|c|c|c|c|}
\hline & ROE & GCRt & GCRt-1 & Lnscale \\
\hline ROE & 1 & & & \\
\hline GCRt & $0.486^{* *}$ & 1 & & \\
\hline GCRt-1 & $0.447^{* *}$ & $0.776^{* *}$ & 1 & 1 \\
\hline Lnscale & 0.226 & $0.578^{* *}$ & $0.632^{* *}$ & \\
\hline
\end{tabular}

Notes: ***, **, * means significant of the coefficient under the level of $1 \%, 5 \%, 10 \%$ 
Table 3. Shows that there exists positive correlation between ROE of Chinese listed banks and green credit loan policy implementation strength in the previous phase, i.e. the implementation of green credit policy can promote the improvement of bank performance.

\section{Conclusion and Suggestion}

This research shows that there exists positive correlation between green loan implementation strength in Chinese listed banks and bank performance. Chinese banks should actively conduct green credit policy, strengthen information transparency, publicize and accept green credit. Effective green credit responsibility mechanism can promote the operation performance in banking industry. It is necessary to further formulate and perfect green credit policy responsibility mechanism, guide banking industry to execute enterprise social responsibilities, and guarantee healthy and sustainable development of green credit.

\section{Acknowledgments}

This research project is supported by Science Foundation of Beijing Language and Culture University (supported by "the Fundamental Research Funds for the Central Universities") (Approval number: 18YJ04001).

\section{References}

[1] Sonia Labatt, Rodney R White. Environmental Finance, New York: John Wiley and Sons, 2002.

[2] Chen Ning, Zhang Ya, Li Shifeng: "Strengthen policy guidance and promote fast development of Chinese green credit", Development Research, 7th issue, 2014.

[3] Li Cheng, Bai Wei, Wang Ye, Li Yushan, "How can green credit policy be effectively implemented by commercial banks? —Studies on evolutionary stable strategy and DID model", South China Finance, 1st issue, 2016.

[4] Tao Qian, "Discussion on the influence mechanism of green credit on bank performance", Macroeconomic Management, 5th issue, 2016.

[5] Zhu Guangyin, Wang Xiaoning, Li Yanru, "Empirical analysis on internal motive of commercial banks' green credit, Finance and Accounting Monthly, 18th issue 2017. 